https://doi.org/10.35339/msz.2019.85.04.17

УДК 616.314.13-001.511-007.251-002.4-079.8

\title{
И.И. Заболотная
}

\section{Донецкий национальный медицинский университет, г. Лиман УСОВЕРШЕНСТВОВАНИЕ МЕТОДОВ ДИАГНОСТИКИ,
КЛАССИФИКАЦИИ МИКРОТРЕЩИН ЭМАЛИ ЗУБОВ
И СПОСОБА ОЦЕНКИ ЭФФЕКТИВНОСТИ ИХ ЛЕЧЕНИЯ}

В клинике часто диагностируют пришеечные поражения: клиновидный дефект, пришеечный кариес и трещины. Представлены результаты применения электрометрического метода в целях диагностики микротрещин твердых тканей зубов. В 16,70 \% случаев диагностированный перед исследованием тип трещин эмали зубов в зависимости от сложности выявления не соответствовал полученным результатам ширины их раскрытия. Рекомендовано перед препарированием пришеечной патологии диагностированные микротрещины эмали вестибулярной поверхности классифицировать как трещины, которые видны после использования дополнительного освещения, высушивания, оптических систем, диагностического окрашивания, определения электросопротивления, использования трансиллюминации и других дополнительных методов исследования (I тип), и трещины, которые заметны невооруженным глазом при обычном освещении (II тип). Его использование позволит не только провести доклиническую диагностику данной патологии, но и оценить эффективность лечебно-профилактических мероприятий. Применение предложенной классификации незавершенных микротрещин будет способствовать повышению эффективности оперативного лечения пришеечных поражений твердых тканей зубов.

Ключевые слова: микротрещчины эмали, диагностика, электрометрический метод, клиновидный дефект, пришеечный кариес, пришеечные поражения.

\section{Актуальность}

Нередко в практической деятельности врач-стоматолог при осмотре зубов обнаруживает микротрещины эмали, хотя не всегда их возможно выявить невооруженным глазом [1]. Опасность наличия этих дефектов состоит в том, что в дальнейшем они могут служить путями проникновения микроорганизмов и протеолитических ферментов, разрушающих ткани зуба, и обеспечивать доступ деминерализующим кислотам к минеральным веществам подповерхностного слоя. Это может стать причиной развития кариозного процесса [2, 3], клиновидных дефектов [4], а также возникновения гиперестезии [1]. В связи с этим важным и одновременно недостаточно разработанным звеном в профилактике патологии твердых тканей зубов является их ранняя диагностика [5] из-за ограниченных возможностей традиционных методов (дополнительного освещения и высушивания поверхности зуба) и маловыраженности клинических признаков начального поражения $[2,6]$.

Высокую распространенность микротрещин эмали определяют с использованием дополнительных методов исследования [2-4]. Применение увеличительных приспособлений (бинокулярной и монокулярной луп) может

(С) И.И. Заболотная, 2019 
повысить точность диагностики до 75 \% [7]. Максимальное количество незавершенных трещин выявляют методом трансиллюминации [2], на котором основан принцип работы многоцелевого аппарата UFL-112 («ЛюксДент», Украина) [3]. Современным эффективным диагностическим методом является оптоволоконная трансиллюминация (Fiber Optic Transillumination) - использование галогеновой лампы и фиброоптического элемента, с помощью которого создают мощный пучок холодного света [7]. Применение цифрового оптоволоконного свечения (DiagnoCam, Kavo) позволяет визуализировать трещины на поверхности эмали зуба на экране монитора в режиме реального времени, однако изображение фиксируется в черно-белых тонах [8]. Другие исследователи для диагностики очагов начальной деминерализации используют метод флюоресценции (светодиодный активатор «LED актив», «MЕДТОРГ+», РФ) [9], так как в трещине вследствие возникающей дезориентации кристаллов аппатита изменяется флюоресценция по сравнению с таковой в области интактной эмали [10]. Применение интраоральной камеры позволяет совместить анатомическое изображение и флюоресцентное излучение тканей зуба, демонстрируя состояние эмали и дентина по всей исследуемой поверхности [7], при этом цветное изображение в режиме реального времени выводят на экран монитора [8]. Однако только отдельные методы используются в ежедневной практике врача-стоматолога в связи с их трудоемкостью, большими временными и финансовыми затратами [5]. Те методы, которые позволяют не только проводить дозонологическую диагностику заболевания, но и оценивать эффективность назначенных лечебнопрофилактических мероприятий, приобретают особую значимость [5, 11]. Таким методом является электрометрия, которая открывает принципиально новые возможности как для практической стоматологии, так и для научных исследований [9]. Благодаря высокой воспроизводимости и хорошей корреляции результатов измерений с данными гистологического анализа электрометрический метод является хорошим дополнением к традиционному клиническому обследованию [7].

Помимо диагностики патологии не меньший интерес представляет классификация микротрещин эмали. В зависимости от визуальных признаков выделяют следующие типы незавершенных трещин:

I - не видны невооруженным глазом на интактных, пломбированных, кариозных зубах без использования дополнительного освещения, высушивания, оптических систем (монокулярной и бинокулярной луп) или использования трансиллюминации (трудно выявляемые), тонкие, поверхностные, вертикальные, «crazy lines»;

II - трещины, которые видны невооруженным глазом при внутриротовом освещении и высушивании без использования дополнительных методов на интактных, пломбированных и кариозных зубах, более глубокие, вертикальные и косые;

III - трещины, которые заметны невооруженным глазом при обычном освещении, пигментированные, окрашиваются метиленовым синим, глубокие, вертикальные, косые, горизонтальные и комбинированные [2].

Представленная систематизация является усовершенствованным вариантом известной классификации трещин в зависимости от сложности их выявления (С.Б. Иванова, 1984): I - очень тонкие, заметные после тщательного высушивания поверхности зуба, при применении окрашивания $1 \%$ раствором метиленового синего, дополнительного освещения и бинокулярной лупы; II - обнаруживаются при дополнительном освещении без дополнительного увеличения; III - определяются невооруженным глазом при обычном освещении [3]. Но данная классификация, на наш взгляд, имеет больше научное значение, чем практическое применение.

Результаты исследований по изучению химического состава, микротвердости эмали и дентина интактных зубов, стенок кариозного процесса и поверхностей, образующих клиновидный дефект, свидетельствуют о том, что данные показатели зависят от глубины микротрещин эмали как интактных зубов, так и с пришеечной патологией (клиновидным дефектом и пришеечным кариесом). В связи с этим недооценка фактора наличия и глубины трещин эмали вестибулярной поверхности может привести к частичному или полному нарушению целостности реставрации, появлению симптомов гиперестезии и дальнейшему прогрессированию пришеечной патологии по периферии реставрации [12-14]. 
Цель настоящего исследования - повышение эффективности диагностики и способа оценки лечения незавершенных микротрещин эмали, оптимизация метода их классификации при оперативном лечении пришеечных поражений твердых тканей зубов.

\section{Материал и методы}

Обследованы 840 интактных зубов обеих челюстей (140 моляров, 280 премоляров, 140 клыков, 280 резцов) 35 пациентов в возрасте 25-54 лет. Диагностировали три типа трещин в зависимости от сложности их выявления (С.Б. Иванова, 1984) [3]. Электропроводность эмали определяли по методике, предложенной Г.Г. Ивановой и В.К. Леонтьевым [9], с помощью аппарата «ДентЭст» (ЗАО «Геософт Дент», РФ) [6].

Апробация способа оценки эффективности лечения микротрещин твердых тканей зубов с законченной минерализацией эмали с помощью электрометрического метода была проведена у 132 пациентов 25-44 лет в течение года. Электропроводность твердых тканей определяли в центральной части дефекта эмали до начала лечения и фиксировали результат (в диапазоне 0,3-2,0 мкА), потом - после реминерализующей терапии (в диапазоне 04,0 мкА). Уменьшение показателей электропроводности после лечения расценивали как подтверждение его эффективности [11].

У 157 пациентов (82 - с клиновидным дефектом, 75 - с пришеечным кариесом) при оперативном лечении пришеечной патологии использовали дифференцированный подход в зависимости от глубины диагностированных микротрещин эмали $[13,14]$. В зубах с пришеечным кариесом профилактическое расширение придесневой стенки проводили при наличии на вестибулярной поверхности дефектов эмали, которые можно определить невооруженным глазом при обычном освещении (III тип), а окклюзионной стенки - при определении микротрещин с использованием дополнительного освещения или красящих веществ (II и I типы соответственно) [13]. В зубах же с клиновидным дефектом максимальное расширение осуществляли в области коронковой поверхности при наличии микротрещин эмали III типа и в зоне десенной поверхности - при дефектах I и II типов [14].

Контрольной группой были 120 пациентов (60 - с клиновидным дефектом, 60 - с при- шеечным кариесом), которым проводили препарирование по традиционной методике без учета наличия и глубины микротрещин эмали $[13,14]$.

\section{Результаты и их обсуждение}

В результате исследования 840 зубов были обнаружены трещины эмали: III типа в $60,24 \%$ случаев, II типа - в $15,71 \%$, I типа (с помощью бинокулярной лупы $(\times 4,5)$ и после окрашивания $1 \%$ раствором метиленового синего) - в $10 \%$ случаев. Но не все трещины окрашиваются, что ставит под сомнение эффективность данного способа диагностики [6]. В связи с этим был использован электрометрический метод для дальнейшего определения распространенности микротрещин эмали. Значения электропроводности 36 зубов (4,29\%) находились в пределах 0,32,0 мкА, что свидетельствовало о наличии дефектов эмали [6].

На протяжении года 132 пациентам были назначены курсы реминерализующей терапии. При ее эффективности (у 108 пациентов $81,82 \%$ ) было зарегистрировано уменьшение величины тока, проводимого исследованной областью и, соответственно, уменьшение электропроводности. При неэффективности реминерализующей терапии (у 24 пациентов $18,18 \%$ ) диагностировали увеличение размеров микротрещин и, соответственно, повышение ее проницаемости и увеличение тока, проводимого исследованной областью. Таким образом, изменение показателей электропроводности твердых тканей зуба (до 4,0 мкА) наблюдали при деминерализации эмали при потере электросопротивления, уменьшение (до 0-0,2 мкА) - при реминерализации эмали [11].

По отдаленным результатам (через год) оперативного лечения пришеечной патологии у 277 пациентов, использование дифференцированного подхода позволяет достичь стабилизации и повысить его эффективность в среднем на 10,66 \% - при пришеечном кариесе, на $11,79 \%$ - при клиновидном дефекте относительно эффективности препарирования по традиционной методике (без учета фактора наличия и глубины микротрещин эмали) $[13,14]$.

Так как подход к препарированию одинаковый при наличии микротрещин I и II типов и клиновидного дефекта и пришеечного кариеca, считаем целесообразным объединить эти 
типы дефектов эмали в одну группу с практической целью. Подтверждением являются результаты исследований с помощью сканирующей электронной микроскопии [4]. В 16,7 \% случаев диагностированный в клинических условиях тип трещин эмали зубов в зависимости от сложности выявления [3] не соответствовал полученным результатам микроскопического определения ширины их раскрытия. Это, на наш взгляд, объясняется тем, что пигментация трещины пищевыми красителями облегчала ее выявление и трещину II типа можно было определить невооруженным глазом при обычном освещении (III тип) либо трещину I типа обнаружить при дополнительном освещении без дополнительного увеличения (II тип) [4]. В связи с этим рекомендуем перед оперативным лечением пришеечной патологии диагностированные незавершенные микротрещины эмали вестибулярной поверхности классифицировать как трещины, которые видны после использования дополнительного освещения, высушивания, оптических систем, диагностического окрашивания, определения электросопротивления, использования трансиллюминации и других дополнительных методов исследования, - I тип, трещины, которые заметны невооруженным глазом при обычном освещении, - II тип.

\section{Выводы}

Применение электрометрического метода способствует эффективной диагностике микротрещин коронковой части зуба, особенно на этапе доклинических проявлений, и может быть методом выбора. Полученные данные станут основанием для назначения реминерализующей терапии, а их динамика позволит оценить ее эффективность. Так как большинство трещин протекает бессимптомно и трудно диагностируются, данный метод и трансиллюминацию можно рекомендовать для обнаружения скрытых повреждений эмали и дентина.

Применение дифференцированного подхода к расширенному препарированию (удалению измененной эмали - участков микротрещин, нависающих краев, и дентина) в зависимости от глубины диагностированных микротрещин эмали (типа согласно классификации), позволит добиться желаемого долгосрочного результата пломбирования, так как фиксация пломбировочного материала будет осуществляться к интактным тканям. Усовершенствование классификации трещин эмали в зависимости от сложности их выявления [3] будет способствовать ее применению в практической стоматологии и тем самым повышению эффективности лечения пришеечных поражений твердых тканей зубов.

\section{Список литературы}

1. Луц̧кая И. К. Научное и клиническое обоснование чувствительности зуба / И. К. Луцкая, О. А. Лопатин // Современная стоматология. - 2005. - № 4. - С. 4-7.

2 Луцүкая И. К. Частота трещин эмали и дентина в постоянных зубах / И. К. Луцкая, Г. С. Ничипорович // Стоматологический журнал. - 2006. - № 2. - С. 87-91.

3. Шевченко В. К. Контроль трещин эмали и дентина зубов в молодом возрасте / В. К. Шевченко, Ю. И. Мастеров // Современная стоматология. - 2001. - № 1. - С. 20-22.

4. Ярова С. П. Особенности распространенности и направленности трещин эмали различных групп зубов / С. П. Ярова, И. И. Заболотная // Вісник стоматології. - 2012. - № 3 (80). - С. 60-64.

5. Сафонова Ю. С. Методи клінічної та доклінічної діагностики уражень твердих тканин зубів / Ю. С. Сафонова // Новини стоматології. - 2009. - № 2. - С. 59-62.

6. Ярова С. П. Диагностика микротрещин твердых тканей зубов с завершенной минерализацией эмали / С. П. Ярова, И. И. Заболотная // Питання експериментальної та клінічної медицини : збірник статей. - Донецьк : Донецький національний медичний університет, 2011. - Вип. 15, т. 3-4. - С. 246249.

7. Гранько C. A. Диагностика начальных кариозных поражений твердых тканей зубов / С. А. Гранько, Д. В. Данилова, Л. В. Белодед // Современная стоматология. - 2017. - № 4. - С. 59-62.

8. Родионова A. C. Современные технологии для ранней диагностики кариеса / А. С. Родионова // Стоматолог-практик. - 2014. - № 4. - С. 36-37.

9. Роль светоиндуцированной флюоресценции и электрометрии в оценочной характеристике и реминерализирующей терапии твердых тканей зуба / Ю. А. Ипполитов, Э. Г. Борисова, С. Н. Панкова [и др.] // Фундаментальные исследования. - 2011. - № 9, ч. 3. - С. 408-410.

10. Phase transformations in a human tooth tissue at the initial stage of caries / P. Seredin, D. Goloshchapov, T. Prutskij, Y. Ippolitov // PLoS One. - 2015. - Vol. 10 (4). - e0124008. - DOI : 10.1371/journal.pone.0124008. 
11. Патент 67241 Україна, МПК А61N1/18 (2006.01). Спосіб оцінки ефективності лікування мікротріщин твердих тканин зубів з закінченою мінералізацією емалі / Ярова С. П., Заболотна I. I. ; заявник та патентовласник Донецький національний медичний університет ім. М. Горького. № u201108654 ; заявл. 11.07.11 ; опубл. 10.02.12, Бюл. № 3.

12. Ярова С. П. Диференційний підхід до оперативного лікування пришийкових уражень твердих тканин зубів / С. П. Ярова, І. І. Заболотна // Новини стоматології. - 2017. - № 3 (92). - С. 84-87.

13.Патент 104318 Україна, МПК А61С5/00 (2006.01). Спосіб лікування пришийкового карієсу зубів / Ярова С. П., Заболотна I. І. ; заявник та патентовласник Донецький національний медичний університет ім. М. Горького. - № u201506608 ; заявл. 06.07.15 ; опубл. 25.01.16, Бюл. № 2.

14.Патент 99693 Україна, МПК А61С5/00 (2015.01). Спосіб лікування клиноподібних дефектів твердих тканин зубів / Ярова С. П., Заболотна І. І. ; заявник та патентовласник Ярова С. П., Заболотна I. I. - № u201403579 ; заявл. 07.04.14 ; опубл. 25.06.15, Бюл. № 12.

\section{References}

1. Lutskaia I.K., Lopatin O.A. (2005). Nauchnoie i klinicheskoie obosnovaniie chuvstvitelnosti zuba [Scientific and clinical rationale for tooth sensitivity]. Sovremennaia stomatolohiia-Modern Dentistry, № 4, pp. 4-7 [in Russian].

2. Lutskaia I.K., Nichiporovich H.S. (2006). Chastota treshchin emali i dentina v postoiannykh zubakh [The frequency of fissures in the enamel and dentin of permanent teeth]. Stomatolohicheskii zhurnal Dental Journal, № 2, pp. 87-91 [in Russian].

3. Shevchenko V.K., Masterov Yu.I. (2001). Kontrol treshchin emali i dentina zubov v molodom vozraste [Control of tooth enamel and dentin cracks at a young age]. Sovremennaia stomatolohiia Modern Dentistry, № 1, pp. 20-22 [in Russian].

4. Yarova S.P., Zabolotna I.I. (2012). Osobennosti rasprostranennosti i napravlennosti treshchin emali razlichnykh hrupp zubov [Features of prevalence and direction of enamel fissures of different groups of teeth]. Visnyk stomatolohii - Dentistry Bulletin, № 3 (80), pp. 60-64 [in Russian].

5. Safonova Yu.S. (2009). Metody klinichnoi ta doklinichnoi diahnostyky urazhen tverdykh tkanyn zubiv [The methods of clinical and pre-clinical diagnostics of hard teeth tissues destrction]. Novyny stomatolohii - News of Dentistry, № 2, pp. 59-62 [in Ukrainian].

6. Yarova S.P., Zabolotnaia I.I. (2011). Diahnostika mikrotreshchin tverdykh tkanei zubov s zavershennoi mineralizatsiiei emali [Diagnostics of microfissures of hard tooth tissues the completed mineralization of dental enamel]. Pytannia eksperymentalnoi ta klinichnoi medytsyny - Issues of Experimental and Clinical Medicine: Digest of articles (Issue 15, vol. 3-4), (pp. 246-249). Donetsk: DonNMU [in Russian].

7. Hranko S.A., Danilova D.V., Beloded L.V. (2017). Diahnostika nachalnykh karioznykh porazhenii tverdykh tkanei zubov [Diagnosis of initial carious lesions of hard tooth tissues]. Sovremennaia stomatolohiia Modern Dentistry, 4, pp. 59-62 [in Russian].

8. Rodionova A.S. (2014). Sovremennyie tekhnolohii dlia rannei diahnostiki kariesa [Modern technologies for early diagnosis of caries]. Stomatoloh-praktik - Dentist-practitioner, № 4, pp. 36-37 [in Russian].

9. Ippolitov Y.A., Borisova E.H., Pankova S.N., Shelkovnikova S.H., Moiseieva N.S. (2011). Rol svetoindutsirovannoi fliuorestsentsii i elektrometrii v otsenochnoi kharakteristike i remineraliziruiushchei terapii tverdykh tkanei zuba [The role of light-induced fluorescence and electrometry in the evaluation characteristic and remineralizing therapy of tooth hard tissues]. Fundamentalnyie issledovaniia - Basic Research, № 9, part 3, pp. 408-410 [in Russian].

10. Seredin P., Goloshchapov D., Prutskij T., Ippolitov Y. (2015). Phase transformations in a human tooth tissue at the initial stage of caries. PLoS One, vol. 10 (4), e0124008, DOI 10.1371/journal.pone.0124008.

11. Yarova S.P., Zabolotna I.I., zaiavnyk ta patentovlasnyk Donetskyi natsionalnyi medychnyi universytet im. M. Gorkoho. (2012). Patent 67241 Ukraina, MPK A61N1/18 (2006.01). Sposib otsinky efektyvnosti likuvannia mikrotrishchyn zubiv z zakinchennoiu mineralizatsiieiu emali [Patent 67241 Ukraine, IPC A61N1/18 (2006.01). Method of evaluating effectiveness of treatment of microfissures of hard tooth tissues the completed mineralization of dental enamel]. № u201108654, stated 11.07.11, published by 10.02.12, newsletter № 3 [in Ukrainian]. 
12. Yarova S.P., Zabolotna I.I. (2017). Dyfferentsiinyi pidkhid do operatyvnoho likuvannia pryshyikovykh urazhen tverdykh tkanyn zubiv [Differentiated approach to operative therapy of precervical injury of dental tissues]. Novyny stomatolohii - News of Dentistry, № 3 (92), pp. 84-87 [in Ukrainian].

13. Yarova S.P., Zabolotna I.I., zaiavnyk ta patentovlasnyk Donetskyi natsionalnyi medychnyi universytet im. M. Gorkoho. (2016). Patent 104318 Ukraina, MPK A61C5/00 (2006.01). Sposib likuvannia pryshyikovoho kariiesu zubiv [Patent [Patent 104318 Ukraine, IPC A61C5/00 (2006.01). Method of treatment of precervical caries of tissues]. u201506608, stated 06.07.15, published by 25.01.16, newsletter № 2 [in Ukrainian].

14. Yarova S.P., Zabolotna I.I., zaiavnyk ta patentovlasnyk Yarova S.P., Zabolotna I.I. (2015). Patent 99693 Ukraina, MPK A61C5/00 (2015.01). Sposib likuvannia klynopodibnykh defektiv tverdykh tkanyn zubiv [Patent 99693 Ukraine, MPK A61C5/00 (2015.01). Method of treatment of wedge-shaped defects of hard tooth tissues]. u201403579, stated 07.04.14, published by 25.06.15, newsletter № 12 [in Ukrainian].

\section{I.I. Заболотна}

\section{УДОСКОНАЛЕННЯ МЕТОДІВ ДІАГНОСТИКИ, КЛАСИФІКАЦІЇ МІКРОТРІЩИН ЕМАЛІ ЗУБІВ ТА СПОСОБУ ОЦІНЮВАННЯ ЕФЕКТИВНОСТІ ЇХНЬОГО ЛІКУВАННЯ}

У клініці часто діагностують пришийкові ураження: клиноподібний дефект, пришийковий карієс та тріщини. Подано результати застосування електрометричного методу з метою діагностики мікротріщин твердих тканин зубів. У 16,7% випадків діагностований перед дослідженням тип тріщин емалі зубів залежно від складності визначення не відповідав отриманим результатам ширини їхнього відкривання. Рекомендовано перед препаруванням пришийкової патології діагностовані мікротріщини емалі вестибулярної поверхні класифікувати як тріщини, які видні після застосування додаткового освітлення, висушування, оптичних систем, діагностичного забарвлення, визначення електроопору, використання трансілюмінації та інших додаткових методів дослідження - I тип, та тріщини, які видні неозброєним оком при звичайному освітленні - II тип. Його використання дозволить не тільки провести доклінічну діагностику даної патології, але й оцінити ефективність лікувально-профілактичних заходів. Застосування запропонованої класифікації незавершених мікротріщин буде сприяти підвищенню ефективності оперативного лікування пришийкових уражень твердих тканин зубів.

Ключові слова: мікротріщини емалі, діагностика, електрометричний метод, клиноподібний дефект, пришийковий карієс, пришийкові ураження.

\section{I.I. Zabolotnaia}

IMPROVEMENT OF METHODS OF DIAGNOSTICS, CLASSIFICATION OF TOOTH ENAMEL MICROFISSURES AND OF METHOD FOR EVALUATING THE EFFECTIVENESS OF THEIR TREATMENT

In clinical practice it is often diagnosed precervical lesions: wedge-shaped defect, precervical caries and fissures. The scientific research reveals results of application of an electrometric method for diagnostics of microfissures of teeth hard tissues. Use of this method will allow not only to make a pre-clinical diagnostics of the given pathology, but also to evaluate efficiency of the taken treatment-and-prophylactic measures. $16.70 \%$ of cases the type of dental enamel fissures diagnosed before research, depending on complexity of their revealing, mismatched the received results of width of their disclosing. So, before the preparation of precervical pathology, we recommend to classify the diagnosed enamel microfissures of vestibular surface into two types: I - fissures, which are visible after using additional lighting, drying, optical systems, diagnostic dye, determining the electrical resistance, using of transillumination and other additional methods; II - fissures, which are visible to the naked eye under normal lighting condition. Application of the proposed qualification of incomplete microfissures will promote to improving the effectiveness of surgical treatment of cervical lesions of teeth hard tissues.

Keywords: enamel microfissures, diagnostics, an electrometric method, wedge-shaped defect, precervical caries, precervical lesions.

Надійшла 17.09.19

\section{Відомості про автора}

Заболотна Ірина Іванівна - кандидат медичних наук, доцент, доцент кафедри стоматології № 2 Донецького національного медичного університету.

Адреса: 84331, м. Краматорськ, Донецька обл., вул. Н. Курченко, 21/25.

Тел.: +38(095)891-67-07.

E-mail: myhelp200@gmail.com.

ORCID: https://orcid.org/0000-0002-3284-0392. 